\title{
Induction and Maintenance of Systemic Acquired Resistance by Acibenzolar-S-Methyl in Three Cultivated Tobacco Types
}

V. Parkunan and C. S. Johnson, Virginia Tech Southern Piedmont Agricultural Research and Extension Center, Blackstone, VA 23824; L. Xu and Y. Peng, Laboratory for Interdisciplinary Statistical Analysis, Department of Statistics, Virginia Tech, Blacksburg, VA 24061; and S. A. Tolin and J. D. Eisenback, Department of Plant Pathology, Physiology, and Weed Science, Virginia Tech, Blacksburg, VA 24061

\begin{abstract}
Parkunan, V., Johnson, C. S., Xu, L., Peng, Y., Tolin, S. A., and Eisenback, J. D. 2013. Induction and maintenance of systemic acquired resistance by acibenzolar-S-methyl in three cultivated tobacco types. Plant Dis. 97:1221-1226.

Induction and maintenance of systemic acquired resistance (SAR) in ' $N$ ' gene containing burley, flue-cured, and oriental tobacco cultivars were assessed by monitoring decreases in the number of local lesions caused by Tobacco mosaic virus (TMV) following treatment with acibenzolar- $S$-methyl (ASM). Leaf samples were collected from lower, middle, and top positions on seedlings at 3-day intervals over 21 days following ASM treatment and subsequent inoculation with TMV under laboratory conditions. Local lesion number for each leaf was recorded 7 days postinoculation. Reductions in TMV local lesion numbers on ASM-treated versus nontreated tobacco varied over time, and differed for each tobacco type. Based on reduced local lesion numbers, SAR

postinoculation, respectively, while oriental tobacco responded by 9 days. SAR was maintained in burley tobacco from 3 to 9 days after ASM application, and from 9 to 15 days after application in oriental tobacco. ASM treatment reduced local lesion numbers in flue-cured tobacco significantly at 6,12 , and 21 days postapplication, but not at 15 and 18 days after treatment. The SAR response was similar among lower, middle, and top leaves with no effect of ASM on response by leaf position, although TMV local lesion numbers were greater on lower leaves than on middle and top leaves 6 days after treatment, but significantly less on lower leaves 18 days after treatment compared to middle and top leaves.
\end{abstract} was induced in burley and flue-cured tobacco by 3 and 6 days
Systemic acquired resistance (SAR) is a form of induced resistance in which plants exhibit resistance to subsequent attack by the same or different pathogen(s) (20). Tobacco mosaic virus (TMV) has been used to demonstrate a SAR response in tobacco plants (Nicotiana tabacum) $(8,17,22,27)$. Tobacco cultivars containing the ' $N$ ' gene possess a gene-for-gene resistance to TMV (39). When lower leaves of tobacco plants of cultivars containing the ' $N$ ' gene (Samsun NN or Xanthi NN) were inoculated with TMV, resistance to TMV was induced in other noninoculated leaves of the same plants, as well as to Tobacco necrosis virus, Phytophthora nicotianae (B. De Haan), and Pseudomonas tabaci Adam. (17,22,27). Induced resistance to TMV was evident by reduction in the formation of hypersensitive local lesions, due to restricted viral replication within infected cells and localization of cell-to-cell movement by the virus $(21,22)$. Later, it was confirmed that other necrotizing pathogens could also induce resistance in tobacco as well as in tomato $(5,39)$.

Acibenzolar- $S$-methyl (ASM), commercially available in the United States as Actigard 50WG (EPA Reg. No. 100-922), is a novel plant SAR elicitor released in 2000 by Syngenta Crop Protection Inc. (Greensboro, NC) $(31,32)$. ASM is a synthetic functional analog of salicylic acid that elicits SAR in many crops within 3 to 4 days, including tobacco $(31,32)$. The SAR induced by ASM provides broad-spectrum resistance to fungi, bacteria, and viruses. The product is registered in the United States for control of blue mold of tobacco (Peronospora tabacina), downy mildew of some brassica leafy vegetables (Peronospora parasitica and $\mathrm{Hy}$ aloperonospora parasitica), black rot of cole crops (Xanthomonas campestris pv. campestris), downy mildew (Peronospora farinosa

Corresponding author: C. S. Johnson, E-mail: spcdis@vt.edu

Accepted for publication 24 March 2013.

http://dx.doi.org:10.1094/PDIS-07-11-0618-RE

(C) 2013 The American Phytopathological Society f. sp. spinaceae) and white rust (Albugo occidentalis) of spinach (Spinacia oleracea L.), and bacterial leaf spot (Xanthomonas campestris pv. vesicatora) and leaf speck (Pseudomonas syringae pv. tomato) of tomato (Solanum lycopersicum L.) (31). ASM has been demonstrated to be effective against Tomato spotted wilt virus (TSWV), Pseudomonas syringae pv. tabaci (causing wildfire and angular leaf spot), Cercospora nicotianae (frogeye leaf spot), and Thanatephorus cucumeris (target spot) on tobacco $(2,13,18,19)$.

The SAR response was initially believed to be equally effective and widespread in related plant species against many different pathogens $(6,23)$. However, some studies showed that intra- and inter-specific variability in SAR exist (6). In oriental Xanthi tobacco, SAR expression occurred approximately 6 days postinfection by a virus (23). On the other hand, in cucumber the SAR was expressed within $7 \mathrm{~h}$ after primary infection by Pseudomonas syringae (25). The enzymes involved in SAR expression were dependent on the type of inducer used (26). In addition, intra-specific variability may be due to variable priming efficiency among cultivars by a specific inducer. For instance, different levels of resistance were observed among different ecotypes of Arabidopsis thaliana (L.) Heynh to Cauliflower mosaic virus (1). Likewise, the mutations in niml (non-inducible immunity) and eds (enhanced disease susceptibility) in A. thaliana were associated with differences in pathogenesis-related protein (PR) production and phenotypic susceptibility to pathogenic bacteria (6). In addition, some barley (Hordeum vulgare L.) breeding lines produced different levels of pathogenesis-related chitinases and glucanases when induced by an elicitor (10). Therefore, the SAR response may differ among genetically distinct types within a single crop species, such as cultivated tobacco. This suggests that the SAR response should be investigated in more than one type of tobacco. Commonly cultivated tobacco types include burley, flue-cured, and oriental tobaccos (33). Although ASM-induced SAR acts systemically (31), there are reports in which chitinases produced after SAR induction differed in activity, spatial distribution within a plant, chitin-binding properties, and catalytic mechanisms $(11,24)$. 
Tobacco foliar fungal and bacterial diseases typically start on lower leaves, and damage is often concentrated in the lower canopy (28). Understanding potential spatial and temporal variations in the SAR response among morphologically different types of tobacco (burley, flue-cured, and oriental) is important to optimize the use of induced resistance for disease management under field conditions. The objectives of this research were to investigate possible intraspecies and spatiotemporal variation in ASM-induced SAR by assessing the duration required for burley, flue-cured, and oriental tobacco types to be induced by ASM, and to maintain enhanced resistance to TMV in the lower, middle, and top leaves of tobacco plants.

\section{Materials and Methods}

A tobacco seedling greenhouse test and detached-leaf local lesion assay were performed in the summers of each of 2005 and 2006, at the Southern Piedmont Agricultural Research and Extension Center in Blackstone, VA. Tobacco cultivars possessing the TMV resistance ' $N$ ' gene $(8,38)$ were used, including burley (cv. TN90), flue-cured (cv. NC297), and oriental (cv. Xanthi NN) types, in combination with inducer treatments (ASM treated and nontreated). Each replication of each treatment combination consisted of a single 288-cell polystyrene tray seeded with one of the TMV resistant cultivars, which was either not sprayed with ASM or sprayed to induce SAR. Within each experiment, all treatment combinations were arranged randomly within four blocks (locations on a greenhouse bench) to account for possible differences in light and air temperature associated with greenhouse bench location, so that the experiments regarding the ASM and tobacco type treatment combinations were arranged in a randomized complete block design (RCBD). In other words, the combinations of four greenhouse bench locations and years (2005 and 2006) created blocking factors, with a total of eight blocks in this study. Trays were floated immediately after seeding on a nutrient solution in a separate wooden bay compartment similar to that typically used for commercial tobacco transplant production (29).

For the local lesion assay, each tray (one of the six combinations of the three tobacco types and two ASM treatments) served as the whole-plot experimental unit. One plant was randomly and independently sampled from among the 288 plants per tray on a 3-day interval for 21 days $(3,6,9,12,15,18$, and 21 days) after ASM application, for a total of seven sample dates. One lower, one middle, and one top leaf were sampled randomly from each selected plant on each sample date. Thus, the individual leaves collected from each of three positions for each sampled plant, on each of the seven sample dates, comprised the 21 subplot experimental units in a split-plot design. A rectangular, $10 \mathrm{~cm}^{2}(4.0 \times 2.5 \mathrm{~cm})$ piece was excised from each of the collected leaves, placed on moist Whatman No. 4 filter paper in one of the three compartments of a $100 \times$ $15 \mathrm{~mm}$ compartmentalized petri dish (Fisher Scientific, Middletown, VA), and evaluated for the number of local lesions resulting from inoculation with TMV.

Seedling preparation and treatments. Seeds of NC297, TN90, and Xanthi NN were planted separately (1 seed/cell) into 288-cell $(24$ cell $\times 12$ cell) polystyrene trays (catalog number $14-2573$, Hummert International, Earth City, MO) that measured $67.6 \times 34.6$ $\times 6.4 \mathrm{~cm}$ (length $\times$ width $\times$ height), and each cell was $2.2 \mathrm{~cm}^{3}$. Trays were each filled with a peat-based potting mix (Carolina Choice Tobacco Mix, Carolina Soil Company, Kinston, NC), seeded, and floated in individual wooden bays, each lined with a construction grade black polyethylene sheet. One week after seeding, the water within each bay was supplemented with 20:20:20 $\mathrm{N}: P: K$ water-soluble fertilizer (Ultrasol, SQM North America, Atlanta, GA) at $200 \mathrm{ppm}$. The water level in each bay was maintained at three-fourths the height of the bay at 3- to 4-day intervals. Four weeks after seeding, when plants had five to six true leaves, four trays of each tobacco type were sprayed with ASM to run-off at the rate of $200 \mathrm{mg} /$ liter distilled water, with an average spray volume of $74.2 \mathrm{ml} /$ tray. A handheld sprayer (1 liter) was used to treat the appropriate trays, after first placing a cardboard barrier along all four sides of the tray to be treated to prevent spray drift. Four trays of each tobacco type were not sprayed to serve as the non-induced treatment. ASM was sprayed over the tray uniformly at a $45^{\circ}$ angle to the surface of the tray from the back to the front of each tray in one pass.

TMV inoculum preparation. Purified TMV was prepared using modifications of a protocol published by Steere (30). Susceptible, young, flue-cured tobacco plants (cv. K326) showing mosaic symptoms were harvested approximately 2 weeks after mechanical inoculation with a common strain of TMV (obtained from Sue Tolin, Virginia Polytechnic Institute and State University, Blacksburg, VA). The mid-rib was removed from each leaf, and the leaves frozen at $-20^{\circ} \mathrm{C}$. Virus was extracted by grinding frozen leaves in a Waring blender for $1 \mathrm{~min}$ in 2.5 to $3.0 \mathrm{ml}$ of $0.2 \mathrm{M}$ dibasic sodium phosphate/g frozen leaf tissue. During grinding, $6 \mathrm{~N} \mathrm{NaOH}$ was added to adjust the $\mathrm{pH}$ to 8.5 , as indicated by Litmus paper. The homogenate was strained through cheesecloth and centrifuged for $10 \mathrm{~min}$ at $12,000 \times \mathrm{g}$. The supernatant was then stirred for $5 \mathrm{~min}$ with $5 \mathrm{~g}$ of charcoal (Norite A)/10 $\mathrm{g}$ of leaf tissue, filtered through Whatman No. 1 paper using a vacuum in a Buchner funnel with Celite (diatomaceous earth) as a filter. Virus was purified from the filtrate by differential centrifugation. The filtrate was first centrifuged at 78,000 $\times g$ for $45 \mathrm{~min}$, and the pellets were resuspended in $1 \mathrm{ml}$ of $0.01 \mathrm{M} \mathrm{Na-EDTA}$ at $\mathrm{pH} 7.5$. After at least $1 \mathrm{~h}$ on ice, the suspension was centrifuged for $10 \mathrm{~min}$ at $18,000 \times g$, followed by high-speed centrifugation of the supernatant for $30 \mathrm{~min}$ at 160,000 $\times g$. The resulting pellets were each resuspended in a total of 1,000 $\mu \mathrm{l}$ of $0.01 \mathrm{M}$ Na-EDTA ( $\mathrm{pH} 7.5$ ). The concentration of final purified TMV was determined spectrophotometrically using an extinction coefficient of 3.2 at $260 \mathrm{~nm} / \mathrm{mg}$ virus.

TMV inoculation and local lesion counting. Purified TMV was diluted to a concentration of $5 \mu \mathrm{g} / \mathrm{ml}$ in $0.05 \mathrm{M}$ phosphate

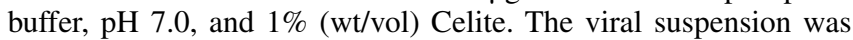
rubbed evenly on each $10 \mathrm{~cm}^{2}$ leaf section using a separate cotton swab for each section. The number of local lesions was counted on each inoculated leaf explant after incubation for 7 days at $22 \pm$ $3^{\circ} \mathrm{C}$.

Statistical analyses. Local lesion counts were log-transformed $\left[\log _{10}(\right.$ count +1$\left.)\right]$ prior to statistical analyses. The transformed counts were analyzed as a split-plot design (SPD) based on the randomized complete block (RCBD) arrangement of whole plots in the greenhouse experiments, i.e., SPD(RCBD, RCBD) using SAS (Version 9.2; SAS Institute Inc., Cary, NC) and JMP (Version 9; SAS). Each combination of year (2005 or 2006) and the four greenhouse bench locations functioned as one of the eight blocking factors. Within each level of each blocking factor, each tray contained a randomly assigned treatment combination of tobacco type and ASM treatment, and served as one of six whole plots. Within each whole plot (greenhouse tray), a total of 21 subplots were formed by the three leaf samples collected from the individual plants on each of the seven sample dates. All block terms were considered random effects, and all treatment effects were considered fixed effects. Treatment means were compared using contrasts.

\section{Results}

Local lesions started appearing 2 to 3 days following inoculation of tobacco plants with TMV, the approximate timing of the first sample period in these experiments. In the initial analysis, the small number of replicates for the whole plot treatments (ASM-bytobacco type combinations) relative to the subplot treatments (leaf position and sample time) resulted in much smaller denominator degrees of freedom for whole plots (35) versus split plots (840) (Table 1). In addition, a number of higher order terms not necessary to preserve the hierarchical structure of the statistical model were not statistically significant $(P \leq 0.05$; Table 1$)$ and were, therefore, dropped from the model, resulting in a "reduced model" (Table 2). The ASM-by-type interaction $(P \leq 0.9419)$ was retained in the reduced model because the time-by-type-by-ASM interaction was statistically significant $(P \leq 0.0035)$. The statistical sig- 
nificance of the main effects and interaction terms for both the full and reduced models were similar (Tables 1 and 2).

ASM application and sampling time, the primary focus of the study, were associated with significant $(P=0.0105$ for sampling time) differences in TMV local lesion numbers (Table 2), but the effects of tobacco type and leaf position on TMV local lesion numbers were not significant $(P=0.0692$ and 0.5720 , respectively; Table 2), nor was the interaction between these two effects $(P=$ 0.9906, Table 1). However, the number of TMV local lesions did vary over time among the three tobacco types $(P<0.0001)$, and this interaction also was affected significantly by ASM treatment $(P=0.0035)$ (Table 2). Differences in TMV local lesion numbers between ASM-treated and nontreated plants were consistent for lower, middle, and top leaves $(P=0.1125$, Table 1$)$, but varied among tobacco types in a time-dependent manner $(P=0.0035$ for Time-by-Type-by-ASM interaction) (Table 2; Fig. 1).

Reductions in the number of TMV local lesions observed on ASM treated versus nontreated burley tobacco were significant at the first observation, 3 days after ASM application $(P=0.036)$, and 9 days post-ASM treatment $(P=0.032)$, and highly significant $(P$ $<0.001) 6$ days post-ASM application, but not significant from 12 to 21 days after treatment (Fig. 1A). Reductions in the number of TMV local lesions observed on flue-cured tobacco leaves were significant $6(P=0.043), 12(P=0.004)$, and $21(P=0.009)$ days after ASM application, but not at 3, 9, 15, and 18 days (Fig. 1B). TMV local lesion numbers were not reduced significantly by ASM treatment of oriental tobacco until 9 days after application $(P=$ $0.003)$, and remained so 12 and 15 days after ASM application $(P$ $<0.001$ and $P=0.025$, respectively), but not thereafter (Fig. 1C).

The effects of sample time on TMV local lesion number also differed significantly among leaf positions $(P<0.0001$; Table 2 and Fig. 2), but this was not affected by whether or not plants had been treated with ASM, as the ASM-by-leaf position-by-time interaction was not significant $(P<0.8787$; Table 1$)$. This was consistent across all three tobacco types. Differences in the mean number of TMV local lesions among leaf positions were not significant

Table 1. Analysis of variance (ANOVA) results for Tobacco mosaic virus (TMV) local lesion numbers from assays performed on tobacco plants not treated or treated with acibenzolar-S-methyl (ASM) in separate experiments performed in each of 2005 and 2006 at the Virginia Tech Southern Piedmont Agricultural Research and Extension Center, Blackstone, VA

\begin{tabular}{|c|c|c|c|c|}
\hline \multirow[b]{2}{*}{ Source of experimental variation ${ }^{a}$} & \multicolumn{2}{|c|}{ Degrees of freedom } & \multirow[b]{2}{*}{$F$ value } & \multirow[b]{2}{*}{$P>F^{b}$} \\
\hline & Numerator & Denominator & & \\
\hline \multicolumn{5}{|l|}{ Main effects } \\
\hline ASM & 1 & 35 & 20.35 & $<0.0001$ \\
\hline Sampling time (Time) & 6 & 840 & 2.69 & 0.0135 \\
\hline Tobacco type (Type) & 2 & 35 & 2.88 & 0.0692 \\
\hline Leaf position & 2 & 840 & 0.54 & 0.5845 \\
\hline \multicolumn{5}{|l|}{ Interactions } \\
\hline Type*Leaf position & 4 & 840 & 0.07 & 0.9906 \\
\hline Time*Type & 12 & 840 & 3.28 & 0.0001 \\
\hline Time*ASM & 6 & 840 & 3.02 & 0.0063 \\
\hline Time*Type*ASM & 12 & 840 & 2.38 & 0.0051 \\
\hline ASM*Leaf position & 2 & 840 & 2.19 & 0.1125 \\
\hline ASM *Leaf position*Time & 12 & 840 & 0.55 & 0.8787 \\
\hline ASM*Type & 2 & 35 & 0.06 & 0.9419 \\
\hline ASM*Type*Leaf position & 4 & 840 & 0.65 & 0.6264 \\
\hline Time*Leaf position & 12 & 840 & 3.23 & 0.0001 \\
\hline Time*Leaf position*Type & 24 & 840 & 0.52 & 0.9729 \\
\hline Time*Type*Leaf position*ASM & 24 & 840 & 0.35 & 0.9986 \\
\hline
\end{tabular}

${ }^{a}$ Overall ANOVA of $\log _{10}$ (number of TMV local lesions + 1) for three tobacco types (burley, flue-cured, and oriental), three leaf positions (lower, middle, and top) from each type of tobacco, and seven sampling times $(3,6,9,12,15,18$, and 21 days after ASM treatment). Blocking factors consisted of eight combinations of two experiments $\times$ four locations per experiment. Whole plot treatment combinations consisted of tobacco type and ASM treatments randomly assigned to each greenhouse tray within each block. Subplots consisted of a full factorial combination of treatments involving leaves sampled from three leaf positions on individual plants randomly selected from each tray on each sample date.

b Probability of the $F$ statistic in the ANOVA.

Table 2. Results from a "reduced model" analysis of variance (ANOVA) of Tobacco mosaic virus (TMV) local lesion numbers from assays performed on tobacco plants either not treated or treated with acibenzolar-S-methyl (ASM) in separate experiments performed in each of 2005 and 2006 at the Virginia Tech Southern Piedmont Agricultural Research and Extension Center, Blackstone, VA ${ }^{\mathrm{a}}$

\begin{tabular}{|c|c|c|c|c|}
\hline \multirow[b]{2}{*}{ Source of experimental variation ${ }^{b}$} & \multicolumn{2}{|c|}{ Degrees of freedom } & \multirow[b]{2}{*}{$F$ value } & \multirow[b]{2}{*}{$P>F^{\mathrm{c}}$} \\
\hline & Numerator & Denominator & & \\
\hline \multicolumn{5}{|l|}{ Main effects } \\
\hline ASM & 1 & 35 & 20.35 & $<0.0001$ \\
\hline Sampling time (Time) & 6 & 910 & 2.80 & 0.0105 \\
\hline Tobacco type (Type) & 2 & 35 & 2.88 & 0.0692 \\
\hline Leaf position & 2 & 910 & 0.56 & 0.5720 \\
\hline \multicolumn{5}{|l|}{ Interactions } \\
\hline Time*Type & 12 & 910 & 3.42 & $<0.0001$ \\
\hline Time*ASM & 6 & 910 & 3.14 & 0.0047 \\
\hline Time*Type*ASM & 12 & 910 & 2.47 & 0.0035 \\
\hline ASM*Type & 2 & 35 & 0.06 & 0.9419 \\
\hline Time*Leaf position & 12 & 910 & 3.36 & $<0.0001$ \\
\hline
\end{tabular}

${ }^{\text {a }}$ Interaction terms not statistically significant $(P \leq 0.05)$ in the original full model ANOVA (see Table 1$)$ were excluded from the reduced model analysis.

${ }^{\mathrm{b}}$ Overall ANOVA of $\log _{10}$ (number of TMV local lesions +1 ) for three tobacco types (burley, flue-cured, and oriental), three leaf positions (lower, middle, and top) from each type of tobacco, and seven sampling times $(3,6,9,12,15,18$, and 21 days after ASM treatment). Blocking factors consisted of eight combinations, from two experiments $\times$ four locations per experiment. Whole plot combinations of tobacco type and ASM treatment were randomly assigned to each greenhouse tray within each block. A full factorial combination of leaves sampled from three leaf positions on individual plants randomly selected from each tray on each sample date functioned as subplots.

c Probability of the $F$ statistic in the ANOVA. 
$3,9,12,15$, or 21 days after treatment. However, TMV local lesions were least numerous on top versus lower leaves 6 days after inoculation $(P<0.0085)$, but greater on top versus lower leaves 18 days after ASM application ( $P \leq 0.0001$; Fig. 2).

\section{Discussion}

The TMV local lesion assay in these experiments provided a simple method to measure quantitatively the SAR response of ASM-treated tobacco plants, clearly demonstrating intra-specific
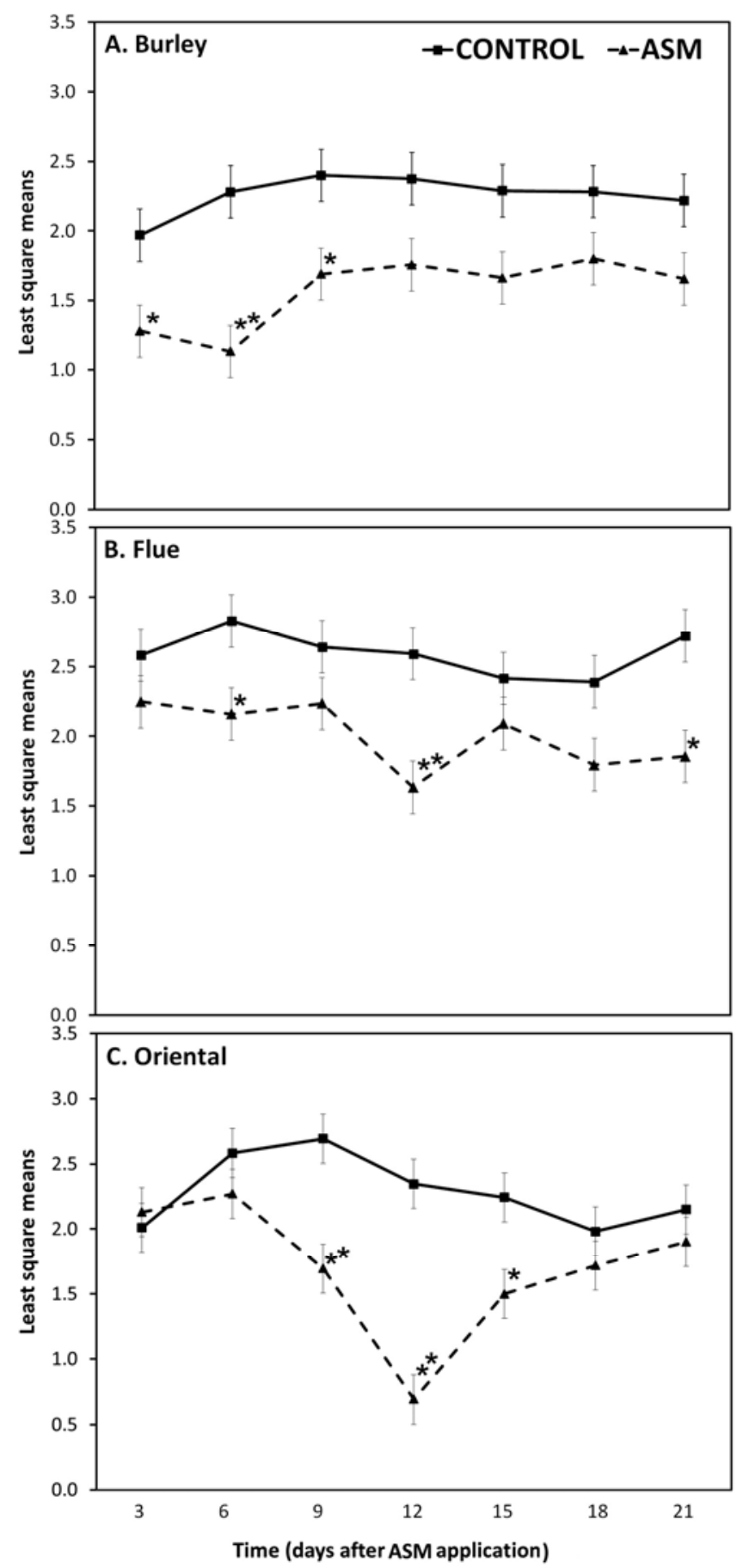

Fig. 1. Tobacco mosaic virus (TMV) local lesion number on leaves of nontreated control plants and acibenzolar-S-methyl (ASM)-treated plants on A, burley, B, flue, and $\mathbf{C}$, oriental tobacco types in Virginia. Data display the least square (LS) means plot of the type of tobacco-by-ASM treatment-by-sampling time (Type ${ }^{\star} \mathrm{ASM}^{\star}{ }^{*} \mathrm{Time}$ ) interaction. Each data point shows the mean and standard error of 24 observations. Asterisks $\left({ }^{*},{ }^{* *}\right)$ indicate differences between nontreated and ASM-treated plants on a particular sample date that were statistically significant (at $P \leq 0.05$ or 0.01 , respectively). and spatiotemporal variation in ASM-induced SAR in tobacco. Reduction in TMV local lesion number following application of ASM gave an indication of the relative SAR level induced and maintained in the tobacco plants, based upon Ross's classical work demonstrating SAR using TMV $(21,22)$. Ross inoculated lower leaves of $\mathrm{N}$-gene tobacco plants with TMV, triggering resistance in upper leaves of the same plant to subsequent infection by TMV, as indicated by reduced number and size of local lesions in the upper, noninoculated leaves $(21,22)$.

Although SAR-related mRNAs have been observed within 4 to $12 \mathrm{~h}$ after treating tobacco with an inducing agent, a "short lag period" is commonly observed before SAR is actually expressed phenotypically $(3,37)$. The results of this study support those of previous greenhouse studies in Georgia with TSWV, which concluded that "high" levels of SAR were observed by 5 to 6 days after ASM application for flue-cured tobacco transplants (15). However, SAR responses can differ inter- and intra-specifically, both in monocotyledons and dicotyledons $(6,23,25)$. SAR expression can even be cultivar dependent $(13,19,35-37)$. The results in this report included burley, oriental, and flue-cured tobacco. Although of the same species, these tobacco types are genetically distinct (33). In this study, significant variation was observed in the temporal pattern of SAR induction among tobacco types, with earlier induction occurring in the burley tobacco cultivar compared to the oriental tobacco and the flue-cured tobacco cultivars. However, cultivars were confounded with tobacco types, so it was not possible to assess if these differences were due to tobacco type or cultivar specifically. Persistence of SAR to TSWV was not monitored in previous Georgia trials (15), but in this study, SAR to TMV appeared to persist on burley tobacco from 3 to 9 days after ASM application, was sporadic on flue-cured tobacco (only significant 6,12 , and 21 days after ASM treatment), and from 9 to 15 days after ASM application on oriental tobacco.

These results differ from reports on other crops in which the response patterns were similar among cultivars, and only the magnitude of the induced resistance response differed $(7,34)$. The patterns and magnitude of pathogenesis-related gene expression were similar among three tomato cultivars after an ASM application in the field, but increases in the general magnitude of SAR response to a second ASM application varied among the cultivars tested (7). Other reports have associated magnitude of the SAR response induced to different levels of constitutive resistance to the pathogen being tested, but both positive and negative correlations have been observed $(13,19,36,37)$. All of the tobacco cultivars tested in this report contained the same $\mathrm{N}$-gene resistance to TMV.

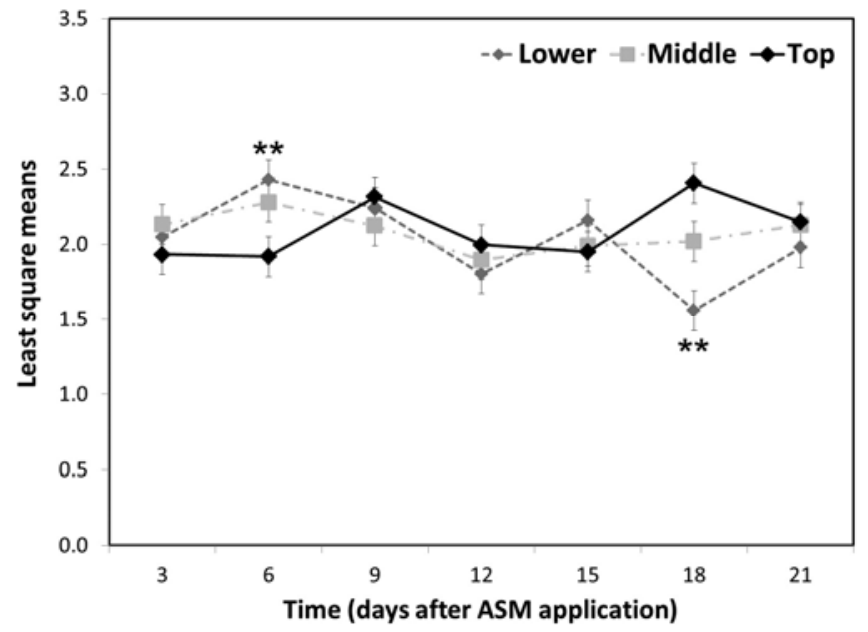

Fig. 2. Mean Tobacco mosaic virus (TMV) local lesion number on lower, middle, and top leaf positions on plants. Each data point displays the log (count of least square means) of the sampling time-by-leaf position (Time*Leaf) interaction in the analysis of variance (see Tables 1 and 2). Differences in the mean number of TMV local lesions among leaf positions $\left({ }^{* *}\right)$ were only significant $(P \leq 0.01) 6$ and 18 days after application of acibenzolar-S-methyl (ASM). 
Uniformity in the expected initiation and duration of induced resistance are important in planning disease management tactics using SAR, particularly with regard to timing applications of inducing agents such as ASM $(9,37)$. Fungicide applications to control tobacco blue mold typically are initiated based upon a forecast of moderate to high risk that infection will occur within $48 \mathrm{~h}$, a shorter time period than the lag time observed between ASM application and SAR induction for each of the tobacco types in this study (14). To avoid disease arising as a result of delayed or incomplete SAR induction, application strategies for foliar tobacco diseases in the field often entail initiating ASM sprays based on crop growth stage, well before disease outbreaks typically occur in a region, or include simultaneous application of a pesticide with ASM in the initial spray (12).

Understanding the spatial distribution of induced resistance within a treated plant could potentially also be important in planning tobacco disease management tactics. Strong within-plant variation was observed in induced resistance in apple arising from herbivore injury (4). In that investigation, induced resistance was initiated within 3 to 4 days, and declined between 8 and 10 days after damage across the leaf positions tested, but responses were strongest and more rapid in the youngest, top leaves. This trend was similar to a recent meta-analysis that found greater levels of plant defense compounds in younger leaves than in older foliage, consistent with an "optimal defense theory" that suggests that plants may prioritize defense responses in young, developing tissue (16). The target spot and blue mold pathogens of tobacco generally initiate epidemics by infecting older, lower leaves first $(14,28)$, while mechanical transmission of TMV is more likely to occur on the "top leaves" that more readily contact contaminated field equipment than leaves lower in the canopy. If resistance is induced more slowly, or functions less at one leaf position compared to others, some pathogens may be controlled more effectively by SAR, while others may remain capable of infecting the induced plant. Although differences were observed in the number of TMV local lesions between older (lower) and younger (top) leaves in this tobacco study, these differences were not associated with SAR induction from the ASM application. Consequently, leaf age or position may not be an important consideration in tobacco disease management strategies employing SAR.

The experiments described in this report were conducted under greenhouse conditions similar to those used in commercial tobacco transplant production, because of the increased control of the experimental conditions compared to field studies. The large number of statistically significant interactions and the significant variation observed in SAR, particularly over time, may reflect the complexity of induced resistance as a host response, not simply to ASM but also to a range of other factors (34-37). In addition to the genotype and plant growth stage effects evaluated in this study, response to resistance-inducing agents has also been associated with environmental conditions, plant nutrition, and other biotic or abiotic stresses or resistance-inducing factors or agents (34-37). In addition, use of SAR for tobacco disease management has been focused primarily on field versus greenhouse conditions $(2,12,13,19)$. Further investigations are required to ascertain the degree to which these greenhouse results may apply to typical field conditions for each of the tobacco types tested, which involve different environmental factors and cultural practices (33). These observations concur with previous conclusions that implementation of induced host resistance for practical plant disease management will require extensive, detailed research within each specific integrated crop management system in order to identify best how to realize the promise of induced resistance (35-37).

\section{Acknowledgments}

This project was supported in part by grants from Altria Client Services and Philip Morris International.

\section{Literature Cited}

1. Callaway, A., Liu, W., Andrianov, V., Stenzler, L., Zhao, J., Wettlaufer, S., Jayakumar, P., and Howell, S. H. 1996. Characterization of Cauliflower mo- saic virus $(\mathrm{CaMV})$ resistance in virus-resistant ecotypes of Arabidopsis. Mol. Plant-Microbe Interact. 9:810-818.

2. Cole, D. L. 1999. The efficacy of acibenzolar-S-methyl, an inducer of systemic acquired resistance, against bacterial and fungal diseases of tobacco. Crop Prot. 18:267-273.

3. Friedrich, L., Lawton, K., Ruess, W., Masner, P., Specker, N., Rella, M. G., Meier, B., Dincher, S., Staub, T., Uknes, S., Métraux, J.-P., Kessman, H. and Ryals, J. 1996. A benzothiadiazole derivative induces systemic acquired resistance in tobacco. Plant J. 10:61-70.

4. Gutbrodt, B., Mody, K., Wittwer, R., and Dorn, S. 2011. Within-plant distribution of induced resistance in apple seedlings: Rapid acropetal and delayed basipetal responses. Planta 233:1199-1207.

5. Hafez, Y. M., Fodor, J., and Király, Z. 2004. Establishment of acquired resistance confers reduced levels of superoxide and hydrogen peroxide in TMV-infected tobacco leaves. Acta Phytopathol. Entomol. Hung. 39:347359.

6. Heil, M. 1999. Systemic acquired resistance: Available information and open ecological questions. J. Ecol. 87:341-346.

7. Herman, M. A. B., Restrepo, S., and Smart, C. D. 2007. Defense gene expression patterns of three SAR-induced tomato cultivars in the field. Physiol. Mol. Plant. Pathol. 71:192-200.

8. Holmes, F. O. 1938. Inheritance of resistance to tobacco mosaic disease in tobacco. Phytopathology 28:553-561.

9. Huang, C.-H., Vallad, G. E., Zhang, S., Wen, A., Balogh, B., Figueiredo, J. F. L., Behlau, F., Jones, J. B., Momol, M. T., and Olson, S. M. 2012. Effect of application frequency and reduced rates of acibenzolar- $S$-methyl on the field efficacy of induced resistance against bacterial spot on tomato. Plant Dis. 96:221-227.

10. Ignatius, S. M. J., Chopra, R. K., and Muthukrishnan, S. 1994. Effects of fungal infection and wounding on the expression of chitinases and $\beta-(1,3)$ glucanases in near-isogenic lines of barley. Physiol. Plant. 90:584-592.

11. Iseli, B., Armand, S., Boller, T., Neuhaus, J.-M., and Henrissat, B. 1996 Plant chitinases use two different hydrolytic mechanisms. FEBS Lett. 382:186-188

12. Johnson, C. S. 2012. Disease and nematode management in field crops: Tobacco. Pages 3.33-3.43 in: Pest Management Guide: Field Crops 2012. E. S. Hagood and D. A. Herbert, Jr., eds. Virginia Coop. Ext. Publ. 456-016.

13. LaMondia, J. A. 2008. Actigard increases fungicide efficacy against tobacco blue mold. Plant Dis. 92:1463-1467.

14. Main, C. E., Keever, T., Holmes, G. J., and Davis, J. M. 2001. Forecasting long-range transport of downy mildew spores and plant disease epidemics. The American Phytopathological Society Feature Story (April 25 through May 22). Retrieved 20 August 2008 from http://www.apsnet.org/online/ feature/forecast/top.htm

15. Mandal, B., Mandal, S., Csinos, A. S., Martinez, N., Culbreath, A. K., and Pappu, H. R. 2008. Biological and molecular analyses of the acibenzolar-Smethyl-induced systemic acquired resistance in flue-cured tobacco against Tomato spotted wilt virus. Phytopathology 98:196-204.

16. McCall, A. C., and Fordyce, J. A. 2010. Can optimal defense theory be used to predict the distribution of plant chemical defenses? J. Ecol. 98:985-992.

17. McIntyre, J. L., Dodds, J. A., and Hare, I. D. 1981. Effects of localized infection of Nicotiana tabacum by Tobacco mosaic virus on systemic resistance against diverse pathogens and an insect. Phytopathology 71:297301.

18. Pappu, H. R., Csinos, A. S., McPherson, R. M., Jones, D. C., and Stephenson, M. G. 2000. Effect of acibenzolar- $S$-methyl and imidacloprid on suppression of tomato spotted wilt Tospovirus in flue-cured tobacco. Crop Prot. 19:349-354.

19. Perez, L., Rodriguez, M. E., Rodriguez, F., and Roson, C. 2003. Efficacy of acibenzolar-S-methyl, an inducer of systemic acquired resistance against tobacco blue mould caused by Peronospora hyoscyami f. sp. tabacina. Crop Prot. 22:405-413.

20. Pieterse, C. M. J., and Van Loon, L. C. 2004. NPR1: The spider in the web of induced resistance signaling pathways. Curr. Opin. Plant Biol. 7:456464.

21. Ross, A. F. 1961. SAR induced by localized virus infection in plants. Virology $14: 340-358$.

22. Ross, A. F. 1966. Systemic effects of local lesion formation. Pages 127-150 in: Viruses of Plants. A. B. R. Beemster and J. Dijkstra, eds. North-Holland, Amsterdam.

23. Ryals, J., Uknes, S., and Ward, E. 1994. Systemic acquired resistance. Plant Physiol. 104:1109-1112.

24. Sahai, A. S., and Manocha, M. S. 1993. Chitinases of fungi and plants: Their involvement in morphogenesis and host-parasite interaction. FEMS Microbiol. Rev. 11:317-338.

25. Schneider, M., Schweizer, P., Meuwly, P., and Metraux, J. P. 1996. Systemic acquired resistance in plants. Pages 303-340 in: International Review of Cytology, Vol. 168. K. W. Jeon, ed. Academic Press, San Diego, CA.

26. Schneider, S., and Ullrich, W. R. 1994. Differential induction of resistance and enhanced enzyme activities in cucumber and tobacco caused by treatment with various abiotic and biotic inducers. Physiol. Mol. Plant Pathol. 45:291-304.

27. Scholthof, K. B. G. 2005. Plant disease lessons: Tobacco mosaic virus. Plant Health Instructor. Retrieved 20 August 2008 from http://www.apsnet. 
org/education/LessonsPlantPath/TMV

28. Shew, H. D., and Lucas, G. B. 1991. Foliar diseases caused by fungi. Pages 5-17 in: Compendium of Tobacco Diseases. H. D. Shew and G. B. Lucas, eds. American Phytopathological Society, St. Paul, MN.

29. Smith, W. D. 1999. Seedling production. Pages 70-75 in: Tobacco Production, Chemistry and Technology. D. L. Davis and M. T. Nielson, eds. Blackwell Science, London.

30. Steere, R. L. 1963. Tobacco mosaic virus: Purifying and sorting associated particles according to length. Science 140:1089-1090.

31. Syngenta Crop Protection. 2001. Revolutionary product now available to prevent disease in California leafy vegetables. Plant Health Progress. Retrieved 20 August 2008 from http://www.plantmanagementnetwork.org/ pub/php/news/blockade/

32. Syngenta Crop Protection. 2008. Retrieved 20 August 2008 from http://www.syngentacropprotection-us.com

33. Tso, T. C. 1999. Seed to smoke. Pages 1-31 in: Tobacco Production, Chemistry and Technology. D. L. Davis, and M. T. Nielsen, eds. Blackwell Science, London.
34. Underwood, N. C. 1998. The timing of induced resistance and induced susceptibility in the soybean-Mexican bean beetle system. Oecologia 114:376-381.

35. Vallad, G. E., and Goodman, R. M. 2004. Systemic acquired resistance and induced systemic resistance in conventional agriculture: Review and interpretation. Crop Sci. 44:1920-1934.

36. Walters, D. R., and Fountaine, J. M. 2009. Practical application of induced resistance to plant diseases: An appraisal of effectiveness under field conditions. J. Agric. Sci. 147:523-535.

37. Walters, D., Walsh, D., Newton, A., and Lyon, G. 2005. Induced resistance for plant disease control: Maximizing the efficacy of resistance elicitors. Phytopathology 95:1368-1373.

38. Whitham, S., Dinesh Kumar, S. P., Choi, D., Hehl, R., Corr, C., and Baker, B. 1995. The product of the Tobacco mosaic virus resistance gene $N$ : Similarity to toll and the interleukin-1 receptor. Cell 78:1101-1115.

39. Whitham, S., McCormick, S., and Baker, B. 1996. The $N$ gene of tobacco confers resistance to Tobacco mosaic virus in transgenic tomato. Proc. Nat. Acad. Sci. 93:8776-8781. 